\title{
SPINAL CORD TRAUMA PATIENTS TREATED IN A TERTIARY HOSPITAL IN PALMAS, BRAZIL
}

\author{
CASUISTICA DE TRAUMA RAQUIMEDULAR TRATADO EM HOSPITAL TERCIÁRIO DE \\ PALMAS, BRASIL
}

\section{PACIENTES CON TRAUMATISMOS DE LA MÉDULA ESPINAL TRATADOS EN UN HOSPITAL TERCER NIVEL DE ATENCIÓN EN PALMAS, BRAZIL}

Danilo Lopes Castro ${ }^{1}$, Gustavo Fernandes leobas' ${ }^{1}$ Maíse Santana Tolentino Marciano Araujo ${ }^{1}$, Itágores Hoffman Lopes Sousa Coutinho", Márcio Antônio de Sousa Figueiredo²

\begin{abstract}
Objective: Traumatic spinal cord injury is one of the leading causes of disability worldwide, mainly related to automobile accidents. It was decided to establish a clinical-epidemiological profile of spinal cord injury (SCI) in Palmas, Brazil. Method: Prospective study at the Public General Hospital of Palmas (HGPP), including all patients admitted in this hospital from January 2011 to February 2012 . Results: They refer to 59 patients, of whom $81.4 \%$ were men and $47.4 \%$ of the victims had up to 40 years. The main mechanism of injury was motor vehicle accidents involving motorcycles. Clinically, the vertebral segment C4-C7 was the most damaged, and most patients were admitted with spinal injury and no neurological deficit (Frankel E). Conclusions: Primary involvement of young men in working age, trauma mainly due to car accidents that are usually associated with the use of alcoholic beverages. Patients admitted with more severe neurological deficits have evolved to milder impairments after conservative or surgical treatment.
\end{abstract}

Keywords: Spinal injuries; Spine; Spinal fractures; Spinal cord; Spinal cord injuries.

\section{RESUMO}

Objetivo: A lesão traumática da medula espinhal é uma das causas mais relevantes de incapacidade no mundo, relacionada principalmente aos acidentes automobilísticos. Decidiu-se traçar o perfil clínico-epidemiológico do trauma raquimedular (TRM), em Palmas, Brasil. Método: Estudo prospectivo, realizado no Hospital Geral Público de Palmas (HGPP), incluindo todos os pacientes admitidos nesse hospital, no período de janeiro de 2011 a fevereiro de 2012. Resultados: São referentes a 59 pacientes, dos quais $81,4 \%$ eram homens e 47,4\% das vítimas tinham até 40 anos. O principal mecanismo de trauma foram os acidentes automobilísticos envolvendo motocicletas. Clinicamente, o segmento vertebral de C4-C7 foi o mais lesado, sendo que a maioria dos pacientes foi admitida com lesão vertebral sem déficit neurológico (Frankel E). Conclusões: Acometimento primordial de homens jovens na faixa etária laboral, com trauma principalmente devido a acidentes automobilísticos que geralmente estão associados ao uso de bebidas alcoólicas. Pacientes admitidos com déficits neurológicos mais severos evoluíram para comprometimentos mais brandos após o tratamento consenador ou cirúrgico.

Descritores: Traumatismos da coluna vertebral; Coluna vertebral; Fraturas da coluna vertebral; Medula espinal; Traumatismos da medula espinal.

\section{RESUMEN}

Objetivo: La lesión medular traumática es una de las principales causas de discapacidad en todo el mundo, principalmente relacionadas con accidentes automovilísticos. Se decidió establecer un perfil clínico-epidemiológico de las lesiones de la médula espinal (LME) en Palmas, Brazil. Método: Estudio prospectivo en el Hospital Público General de Palmas (HGPP), incluyendo todos los pacientes ingresados en este hospital desde enero de 2011 a febrero de 2012. Resultados: Se refieren a 59 pacientes, de los cuales el 81,4\% eran hombres y el 47,4\% de las víctimas tenían hasta 40 años. El principal mecanismo de trauma fueron los accidentes de tráfico con motocicletas. Clínicamente, el segmento vertebral C4-C7 fue el más dañado, y la mayoría de los pacientes con lesión de la médula fue admitida sin déficit neurológico (Frankel E). Conclusiones: Implicación primaria de hombres jóvenes en edad laboral, trauma debido principalmente a los accidentes de tráfico que se asocian generalmente con el uso de bebidas alcohólicas. Los pacientes ingresados con déficit neurológicos más graves han evolucionado para deterioros leves después del tratamiento conservador o quirúrgico.

Descriptores: Traumatismos vertebrales; Columna vertebral; Fracturas de la columna vertebral; Médula espinal; Traumatismos de la médula espinal.

\section{INTRODUCTION}

Despite advances in the treatment of complications, and known prevention strategies, spinal cord injuries $(\mathrm{SCl})$ are still an important cause of morbidity and mortality, ${ }^{1,2}$ and involve high costs related to lengthy treatment and rehabilitation. ${ }^{3}$ Moreover, the fact that it affects mainly those in the economically active age group (and of these, mostly males), generates another set of issues, as they have

1 Universidade Federal do Tocantins, Department of Medicine, Palmas, TO, Brazil.

2 Hospital Geral Público de Palmas Dr. Francisco Ayres, Department of Neurosurgery/Neurology, Palmas, TO. Brazil. 
to live with limiting motor, sensory and autonomic dysfunctions, with economic and psychosocial consequences. ${ }^{4,5}$

Within this scenario, SCls are linked to certain habits, such as impulsiveness, exposure to risks such as violence, alcohol abuse, imprudence, or reckless driving. ${ }^{6-8}$ As a result, factors such as falling from a height, wounds caused by firearms or so called cold weapons (knives and the like), diving into shallow water, and motor vehicle accidents are the factors most closely related to the mechanisms of this type of injury. ${ }^{8}$

It is known that the greater the energy dissipated during the trauma, the more complex its mechanism (involving more sectors or higher sectors of the spine), and the more restricted the immediate and adequate access to health services, the higher the morbidity and mortality rates will be. ${ }^{9}$

It is estimated that around 12,000 new cases occur each year in the United States, ${ }^{10}$ while in Brazil, there are around 6000 to 8000 of $\mathrm{SCl}$ each year. ${ }^{11}$ Despite these high rates, knowledge of traumatic spinal cord injury is still limited, and is often left unreported, leading to a lack of knowledge of its actual incidence, and its impacts. ${ }^{12}$

In view of this uncertain epidemiological scenario, and the need for further investigation of the main and adjuvant risk factors related to $\mathrm{SCl}$, as well as the methods of approach and treatment, it was decided to explore the situation of the capital city of Tocantins, given that in 2011, it had the highest recorded mortality rates due to motor vehicle accidents, ${ }^{13}$ one of the main mechanisms of this kind of trauma. ${ }^{14}$

This investigation, besides exploring the epidemiological field, allows us to contemplate the approach to clinical aspects, providing an analysis of the neurological status, the treatment, and the short-term effects on morbidity. In brief, it seeks to gain an understanding of the local scenario, which in turn, will enable the implementation of control strategies and health policies to prevent and minimize the consequences of these injuries. ${ }^{9}$ This study, therefore, aimed to analyze the clinical and epidemiological characteristics of spinal injury in patients treated at a tertiary hospital in the municipality of Palmas-TO (state of Tocantins).

\section{METHODS}

A prospective study was conducted at the Hospital Geral Público de Palmas (HGPP), Department of Neurosurgery/Neurology. All the patients admitted to this hospital from January 2011 to February 2012 with a diagnosis of traumatic spinal fracture, who required hospitalization for more than 96 hours, and who agreed to take part in the survey through the signing of an Informed Consent Form (ICF) by the patient or their guardian, were included in the study. All patients hospitalized due to complications of a traumatic event occurring prior to the data collection period, those with pathological spinal fractures, or those who did not agree to take part in the survey were excluded. The data were collected through a questionnaire created and filled out by the researchers, by means of an interview with the patient and/or companion, associated with the analysis of medical charts. The data were tabulated and evaluated using the Epi Info ${ }^{\circledR}$ 3.5.1 program (Centers for Disease Control and Prevention, Atlanta, United States). Absolute and relative frequencies were calculated for the following variables: gender; age group of the victim; place of occurrence; day of the week; cause of injury; Frankel scale upon patient admission and discharge; level of injury; self-reported use of alcoholic beverage; type of vehicle involved, and associated injuries. The existence of a statistically significant correlation between some variables was evaluated using the chi-squared test, allowing a significance level of $p<0.05$. The study followed all the precepts of the Declaration of Helsinki, and was approved by the Institutional Review Board of Universidade Federal do Tocantins (IRB-UFT), under opinion number 075/2010.

\section{RESULTS}

The results presented refer to 59 patients. It was noted that $81.4 \%(n=48)$ of the patients were men and $47.4 \%(n=28)$ of the victims were aged 40 years or under. (Table 1) Among the male patients, the age group most affected was $31-50$ years $(50 \% ; n=24)$, and among the female patients, $51-80$ years $(45.5 \% ; n=5)$. Most of the injuries (55.9\%; $n=33$ ) occurred on weekends (considering Fridays, Saturdays and Sundays). Of the causes identified: $62.7 \%$ $(n=37)$ were victims of motor vehicle accidents (MVAs), 30.6\% $(n=18)$ of falls and $3.4 \%(n=2)$ of diving into shallow waters. (Table 2$)$ MVAs were the primary cause of injury in both sexes and in all age groups, representing $60.4 \%(n=29)$ among men and $72.7 \%(n=8)$ among the women. Of these MVAs, in $40.5 \%(n=15)$ of cases the accident victim was the driver or occupant of a car, and in $54.1 \%$ $(n=20)$, the victim was riding a motorcycle. (Table 3) Of all the MVA victims, $22 \%(n=13)$ declared that they were under the effect of alcohol at the time of the traumatic event. Of these, $84.6 \%(n=11)$ were victims of motor vehicle accidents, $7.7 \%$ of aggression $(n=1)$ and $7.7 \%(n=1)$ of general falls. The C4-C7 segment was the most affected, encompassing $33.8 \%(n=22)$ of a total of 65 injuries, with 6 patients injuring two or more segments. Musculoskeletal trauma was associated with SPI in $11.9 \%(n=7)$ of the patients while cranioencephalic trauma occurred in $10.2 \%(n=6)$. Of all the cases, $59.3 \%(n=35)$ were submitted to interventionist conduct. (Table 2) The subjects were assessed for neurological impairment (NI) and total motor deficit (TMD) in both admission and discharge. In relation to $\mathrm{NI}, 22.3 \%(n=13)$ of the patients were admitted to hospital with a Frankel score of $A$, and $39 \%(n=23)$ with a Frankel score of $E$. Of the patients who presented with Frankel $A$ and $B$ upon admission, 83.3\% $(n=15)$ were victims of MVAs, and $16.3 \%(n=3)$ of falls $(p=0.1251)$.

Table 1. Epidemiological distribution of patients with spinal injury treated at the Hospital Geral Público de Palmas from January 2011 to February 2012.

\begin{tabular}{c|c|c}
\hline Variable & $\mathbf{n}$ & Percentage (\%) \\
\hline Gender & & \\
\hline Male & 48 & 81.4 \\
\hline Female & 11 & 18.6 \\
\hline Age Group (years) & & \\
\hline $0-20$ & 4 & 6.8 \\
\hline $21-30$ & 12 & 20.3 \\
\hline $31-40$ & 12 & 20.3 \\
\hline $41-50$ & 16 & 27.1 \\
\hline 51 or over & 15 & 25.4 \\
\hline$n=$ number of individuals & &
\end{tabular}

Table 2. Distribution of patients with spinal injury treated at the Hospital Geral Público de Palmas from January 2011 to February 2012 according to associated causes and deaths.

\begin{tabular}{c|c|c}
\hline Variable & $\mathbf{n}$ & Percentage (\%) \\
\hline Cause of Trauma & & \\
\hline General Falls & 9 & 15.2 \\
\hline Fall from Scaffolding & 6 & 10.2 \\
\hline Fall from Ladder & 1 & 1.7 \\
\hline Fall from Own Height & 2 & 3.4 \\
\hline Motor Vehicle Accident & 37 & 62.7 \\
\hline Diving into Shallow Water & 2 & 3.4 \\
\hline Aggression & 1 & 1.7 \\
\hline Firearm Wound & 1 & 1.7 \\
\hline Death & & 5.1 \\
\hline Yes & 3 & 94.9 \\
\hline No & 56 &
\end{tabular}

$\mathrm{n}=$ number of individuals 
Upon discharge from hospital, $11.9 \%(n=7)$ left with Frankel $A$, and $52.5 \%(n=31)$, with Frankel E. (Figure 1) At the time of discharge, $91.7 \%(n=11)$ of the patients with Frankel $A$ and $B$ were victims of MVAs and $8.3 \%(n=1)$ of falls $(p=0.0760)$. Of the 12 patients admitted with Frankel $A, 84.6 \%(n=11)$ underwent interventionist conduct, and $41.7 \%(n=5)$ evolved to a less serious neurological lesion at the time of discharge $(p>0.05)$. During the hospital stay, $5.1 \%(n=3)$ of the patients died due to causes not directly related to the SCl. (Table 2)

Table 3. Factors related to motor vehicle accidents as a cause of spinal trauma in patients treated at the Hospital Geral Público de Palmas from January 2011 to February 2012

\begin{tabular}{c|c|c}
\hline Variable & $\mathbf{n}$ & Percentage (\%) \\
\hline Type of Vehicle Involved & & \\
\hline Motorcycle & 20 & 54.1 \\
\hline Car & 15 & 40.5 \\
\hline Other & 2 & 5.4 \\
\hline Self-reported Use of Alcoholic Beverage & & \\
\hline Yes & 11 & 29.7 \\
\hline No & 26 & 70.3 \\
\hline
\end{tabular}

$\mathrm{n}=$ number of individuals

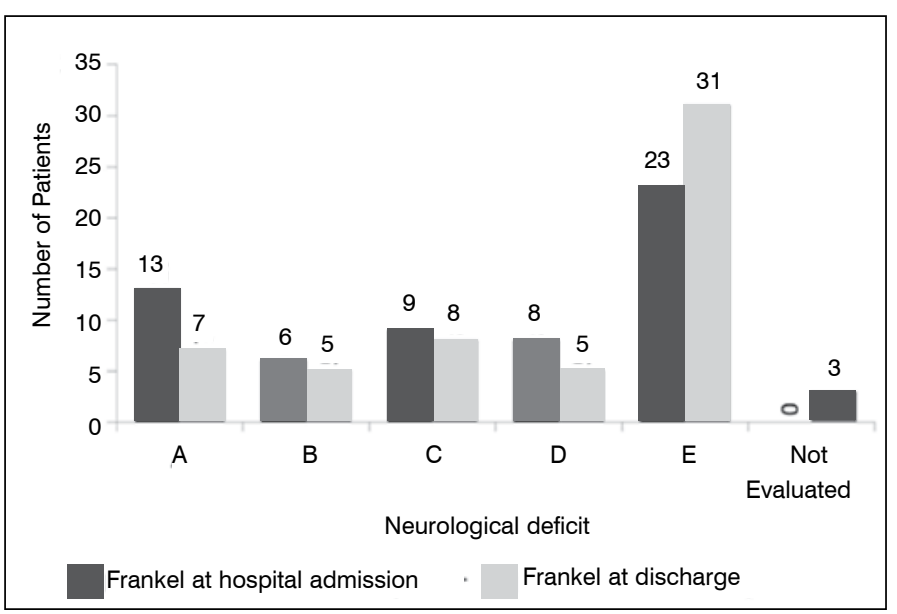

Figure 1. Neurological injury measured by the Frankel Scale upon hospital admission and discharge. Palmas, Tocantins, Brazil, 2011 to 2012.

\section{DISCUSSION}

There is considerable global variation in the distribution by gender and age group of SCl. Recent literature reviews indicate that average age at the time of injury ranges from 26.8 to 55.5 years, and that the majority of studies show a predominance of men, although the proportion of these to each woman affected varies significantly. ${ }^{15,16}$ Other reviews also highlight, in the majority of studies, the appearance of bimodal age distribution of $\mathrm{SCl}$ in some countries, peaking among young adults aged from 15 to 29 years, caused by collisions involving automotive vehicles, violence and sports, and another growing peak among people aged 65 years or over, primarily caused by falls. ${ }^{16,17}$ However, despite this tendency for bimodal distribution, $\mathrm{SCl}$ continues to occur especially among young men of economically active age. ${ }^{14}$ Consistent with the literature, in this study a statistically significant involvement of male individuals was noted, at a proportion of 4.36:1 when compared to women, with predominant incidence in the 21-50 year age group, who represent more than two thirds of all cases in the period studied.

While the greater incidence among men is in the 31 to 50 year age range, among women, there was a predominance of more advanced ages at injury. This may be due to the fact that males are more exposed hazardous situations, such as accidents and violence, when adolescents or young adults.

In most countries motor vehicle accidents are indicated as the most common mechanism of $\mathrm{SCl}$, followed by falls, pinpointed as the predominant cause in individuals over 60 years of age. ${ }^{15,16} \mathrm{Ac}$ cording to Chiu et al. ${ }^{18}$ this presentation is common in developed countries, yet in most developing countries, falls are considered the principal cause. However, Lee et al. ${ }^{19}$ proposed that transportation accidents are stable or decreasing in developed countries, but increasing in developing countries due to the greater presence of vehicles lacking safety devices, more precarious roads, inefficient supervision, and a safety culture that is not widely disseminated.

However, there is considerable variation in the injury mechanisms reported by the various studies, possibly due to geographical and cultural differences, and to different definitions and methodological designs. As observed on a global scale, in this study, motor vehicle accidents represented the most important cause of $\mathrm{SCl}$, followed by falls. A similar profile was noted by Vasconcelos and Riberto ${ }^{20}$ and Morais et al. ${ }^{21}$ in other Brazilian studies, while Fernandes et al., ${ }^{22}$ Frison et al. ${ }^{23}$ and Lee et al. ${ }^{19}$ reported falls as the primary cause.

Studies also vary with regards to the type of vehicle the victim was using at the time of the accident, ${ }^{20-22}$ possibly as a result of environmental variations and/or variations in the local fleet of vehicles. In the study conducted, we noted that $54.1 \%$ of MVAs involved motorcycles, probably corroborated by the high number of this type of vehicle on the roads, the most common vehicle in the state of Tocantins, corresponding to $35.62 \%(158,024)$ of the total fleet in February 2012. ${ }^{24}$

Moreover, most of the traumatic events studied occurred on weekends, a period when alcohol consumption by the population exposed to this type of injury is intensified, and eleven of the thirteen victims of SCI who reported that they were under the effect of alcohol suffered MVAs. According to Furlan and Fehlings, ${ }^{25}$ blood alcohol levels upon admission did not show any correlation with mortality, neurological or functional deficit over the first year after injury in humans; however, alcohol consumption is indicated as the main risk factor for the associated occurrence of cranial trauma in traumatic spinal cord injuries. ${ }^{15}$ While in our sample, cranioencephalic trauma was the second most common type of associated lesion, Morais et al. ${ }^{21}$ reported it to be the most frequent variant.

Moving on to the clinical characterization of $\mathrm{SCl}$, the vertebral segment C4-C7 was the most affected segment. Cervical injuries present a growing incidence worldwide, mainly driven by those located at C1-C4 which are becoming increasingly significant and are causing an increase in the number of ventilator-dependent patients. ${ }^{16}$ The predominant level of injury, however, is widely variable among studies. ${ }^{21-23}$

A surgical approach was adopted in more than half of the victims in this study after the detection of instability of the vertebral segment, and ranged from simple stabilization with steel wire, to decompression and vertebral fixation techniques with screws and plates, as well as the use of implants for vertebral bodies. In $35.6 \%$ of cases the approach was conservative, using a neck brace, Jewett brace, Putti brace or plaster case immobilization, bed rest, analgesia and subsequent outpatient follow-up. Fernandes et al., ${ }^{22}$ in turn, reported that $88 \%$ of the cases in their study were treated surgically.

The data showed that the majority of patients were admitted with vertebral lesion without neurological deficit (Frankel E); however, the victims of MVAs had more severe spinal cord damage than those injured by other causes. Likewise, Pereira et al. ${ }^{26}$ fail to detect neurological lesion in most of their sample, but do not distinguish neurological deficit by its etiology. On the other hand, Fernandes et al. ${ }^{22}$ indicate Frankel $\mathrm{E}$ as the most frequent score upon admission, even among those victims of MVAs.

An improvement in initial neurological status was also observed over the course of the hospital stay, expressed by a smaller proportion of patients with Frankel A upon discharge. However, almost all the patients who left the hospital with Frankel $A$ and $B$ were victims of MVAs, evidencing that this type of accident results in lesions with more difficult recovery. 
Due to the methodological design of the study, it was not possible to study those SCls that resulted in death at the site of the accident. The deaths observed refer to those that occurred in the in-hospital environment, and resulted from complications due to associated systemic conditions or complications of the actual SCI. Accordingly, the data presented here underestimate global mortality by this specific cause at the location studied, requiring further research with a methodological design that includes deaths occurring outside the hospital setting.

Lethality due to $\mathrm{SCl}$ in the immediate phase has declined in recent decades ${ }^{15}$ possibly due to improvements in preadmission and in-hospital support offered to these patients. However, in cervical injuries, the risk of death due to respiratory complications remains relatively high ${ }^{15}$ Corroborating this statement, in most of the deaths recorded by Morais et al., ${ }^{21}$ the lesion occurred in the cervical area and was associated with respiratory complications. Higher cervical lesions are a more serious condition, with a greater risk of evolving to death while still at the site of the accident, or in the first few hours after hospital admission. ${ }^{21}$

\section{CONCLUSION}

At the location studied, we noted a greater incidence of $\mathrm{SCls}$ in young men of working age, caused mainly by motor vehicle accidents, generally associated with the use of alcohol, and usually responsible for more severe deficits, which persist at the time of hospital discharge even after interventionist conduct. With the increase in longevity, more victims have the potential to live with this limiting or incapacitating condition for a longer period of their lives, possibly in association with complications, demanding health care with growing economic and social impacts.

All authors declare no potential conflict of interest concerning this article.

\section{REFERENCES}

1. An HS. Principles and techniques of spine surgery. Baltimore: Williams \& Wilkins: 1997. p. 295-330.

2. Botelho RV, de Souza Palma AM, Abgussen CM, Fontoura EA. Traumatic vertical atlantoaxial instability: the risk associated with skull traction. Case report and literature review. Eur Spine J. 2000;9(5):430-3.

3. Sekhon LH, Fehlings MG. Epidemiology, demographics, and pathophysiology of acute spinal cord injury. Spine (Phila Pa 1976). 2001;26(24 Suppl):S2-12.

4. Furlan JC, Fehlings MG. Cardiovascular complications after acute spinal cord injury: pathophysiology, diagnosis, and management. Neurosurg Focus. 2008;25(5):E13.

5. Noreau L, Proulx P, Gagnon L, Drolet M, Laramée MT. Secondary impairments afte spinal cord injury: a population-based study. Am J Phys Med Rehabil. 2000;79(6):526-35.

6. Krause JS. Factors associated with risk for subsequent injuries after traumatic spinal cord injury Arch Phys Med Rehabil. 2004:85(9):1503-8.

7. O'Connor PJ. Trends in spinal cord injury. Accid Anal Prev. 2006;38(1):71-7.

8. Tate DG, Forchheimer MB, Krause JS, Meade MA, Bombardier CH. Patterns of alcohol and substance use and abuse in persons with spinal cord injury: risk factors and correlates. Arch Phys Med Rehabil. 2004:85(11):1837-47.

9. Furlan JC, Sakakibara BM, Miller WC, Krassioukov AV. Global incidence and prevalence of traumatic spinal cord injury. Can J Neurol Sci. 2013;40(4):456-64

10. Spinal cord injury facts and figures at a glance. J Spinal Cord Med. 2011;34(6):620-1.

11. Defino HLA. Trauma raquimedular. Medicina, Ribeirão Preto. 1999;32(4):388-400.

12. Tuono VL. Traumas de coluna no Brasil: análise das internações hospitalares [dissertação]. Ribeirão Preto: Faculdade de Saúde Pública, Universidade de São Paulo: 2008.

13. Waiselfisz JJ. Mapa da violência 2013: acidentes de trânsito e motocicletas. Rio de Janeiro: CEBELA; 2013.

14. Cripps RA, Lee BB, Wing P, Weerts E, Mackay J, Brown D. A global map for traumatic spinal cord injury epidemiology: towards a living data repository for injury prevention. Spinal Cord. 2011;49(4):493-501.

15. Hagen EM, Rekand T, Gilhus NE, Grønning M. Traumatic spinal cord injuries-incidence, mechanisms and course. Tidsskr Nor Laegeforen. 2012;132(7):831-7.

16. Devivo MJ. Epidemiology of traumatic spinal cord injury: trends and future implications. Spinal Cord. 2012:50(5):365-72.

17. van den Berg ME, Castellote JM, Mahillo-Fernandez I, de Pedro-Cuesta J. Incidence of spinal cord injury worldwide: a systematic review. Neuroepidemiology. 2010;34(3):184-92

18. Chiu WT, Lin HC, Lam C, Chu SF, Chiang YH, Tsai SH. Review paper: epidemiology of traumatic spinal cord injury: comparisons between developed and developing countries. Asia Pac J Public Health. 2010;22(1):9-18.

19. Lee BB, Cripps RA, Fitzharris M, Wing PC. The global map for traumatic spinal cord injury epidemiology: update 2011, global incidence rate. Spinal Cord. 2014;52(2):110-6.

20. Vasconcelos ECLM, Riberto M. Caracterização clínica e das situações de fratura da coluna vertebral no município de Ribeirão Preto, propostas para um programa de prevenção do trauma raquimedular. Coluna/Columna. 2011:10(1):40-3.

21. Morais DFM, Spotti AR, Cohen MI, Mussi SE, Neto JSM, Tognola WA. Perfil epidemiológico de pacientes com traumatismo raquimedular atendidos em hospital terciário. Coluna/ Columna. 2013:12(2):149-52.

22. Fernandes RB, Gomes EGF, Gusmão MS, Amorim DCAJ, Simões MT, et al. Estudo clínico epidemiológico das fraturas da coluna vertebral. Coluna/Columna. 2012;11(3):230-3.

23. Frison VB, Teixeira GO, Oliveira TF, Resende TL, Netto CA. Estudo do perfil do trauma raquimedular em Porto Alegre. Fisioter Pesq. 2013:20(2):165-71.

24. Ministério das Cidades. Departamento Nacional de Trânsito - DENATRAN. Frota 2012. Disponivel em: http://www.denatran.gov.br/frota.htm. Acessado em 10 de dezembro de 2014.

25. Furlan JC, Fehlings MG. Blood alcohol concentration as a determinant of outcomes after traumatic spinal cord injury. Eur J Neurol. 2013;20(7):1101-6.26.

26. Pereira AFF, Portela LED, Lima GDA, Carneiro WCG, Ferreira MAC, Rangel TAM, et al. Avaliação epidemiológica das fraturas da coluna torácica e lombar dos pacientes atendidos no Serviço de Ortopedia e Traumatologia do Hospital Getúlio Vargas em Recife/PE. Coluna/Columna. 2009;8(4):395-400. 